\title{
Reviving calm technology in the e-tourism context 电子旅游环境下平静技术的振兴
}

\begin{abstract}
Tourism industry practitioners should understand the controversial nature of the information and communication technology (ICT) proliferation to ensure the ICT solutions do not consume too much of their attention, thus jeopardizing consumer enjoyment of tourism services. The concept of calm technology or calm design serves this purpose. Calm design suggests that technology should quietly recede in the background and come into play with users when and if required, thus delivering and/or enhancing a desired experience. Although this concept is of relevance to e-tourism, until recently, it has never been considered within. This is where this paper contributes to knowledge as, for the first time, it introduces calm design into the e-tourism context and critically evaluates the determinants of its broader adoption within the tourism industry. It positions calm design within the etourism realm, discusses its implications for customer service management, supply chain management and destination management, and discloses opportunities for future research.
\end{abstract}

\section{摘要}

旅游业从业人员应了解信息和通信技术扩散的争议性, 以确保信息与通信技术解决方案不会消 耗他们过多的注意力，从而损害消费者对旅游服务的享受。平静技术或平静设计的概念就是为 了这个目的。平静设计表明, 技术应该退居幕后, 并在用户需要时发挥作用, 从而提供和/或 增强理想的体验。虽然这一概念与电子旅游相关，但从未在其内部得到考虑。本文的贡献即在 于第一次将平静设计引入到电子旅游环境中, 并批判性地评估了其在旅游业中广泛采用的决定 性因素。本文将平静设计置于电子旅游环境下，讨论其对客户服务管理、供应链管理和目的地 管理的影响，并揭示未来研究的机会。

Keywords: calm technology; information and communication technology; tourism industry; supply chain; destination management

关键词 : 平静技术; 信息与通信技术; 旅游业; 供应链; 目的地管理。 


\section{Introduction}

Information and communication technology (ICT) plays a crucial, and yet controversial, role in tourism. The positive impact of ICT has been systematically examined (Law, Buhalis, \& Cobanoglu, 2014; Sigala, 2018) while significantly less attention has been paid to the shortcomings of ICT application in tourism (Dickinson, Hibbert, \& Filimonau, 2016; Gretzel, 2014; Paris, Berger, Rubin, \& Casson, 2015; Pearce \& Gretzel, 2012), alongside the solutions to overcome these. Indeed, with increased ICT uptake, the frictions between the consumer and the desired experience of consuming tourism services can manifest more explicitly and frequently, thus resulting in a number of the human-technology interaction issues (Case, 2015a; Li, 2017; Yoo, Goo, Huang, Nam, \& Woo, 2017). For example, the friction can be caused due to user's unfamiliarity with ICT during the time of its first use or because of the misalignment of the ICT solutions with human behavior, i.e. when technology fails to anticipate how consumers will use it (First Round Review, 2017). As a result, some of the most common shortcomings of the ICT application in tourism refer to information overload (Frás, Rodruez, \& Castanda, 2008; Magnini, 2017), technostress (Lee, Chang, Lin, \& Cheng, 2014), difficulties in use (Benckendorff, Sheldon, \& Fesenmaier, 2014), technological interferences or glitches (Neuhofer, Buhalis, \& Ladkin, 2015b), the problem of 'value codestruction’ (Plé \& Chumpitaz Cáceres, 2010; Sigala, 2017) or depersonalisation of tourist experiences (Tarlow, 2011). Thus, applying ICT in tourism can hamper the successful delivery of travel and tourist services. For example, a voice-recognition system of a selfcheck-in kiosk in a busy airport can frustrate (Case, 2015a); and a mobile travel guide application can confuse given that it is packed with generic, and often irrelevant, information (Meehan, Lunney, Curran, \& McCaughey, 2013). In essence, by drawing consumers’ attention to itself, for a variety of reasons, ICT unnecessarily spends the satisfaction of consuming tourism service. 
The above mentioned issues have so far been mostly set aside by ICT developers in the pursuit of short-term profits attributed to increased technology sales or due to the sustained novelty effect assigned to technology use in tourism (Gronflaten, 2009; Guttentag, 2010; Jung, Kim, \& Farrish, 2014; Szutowski, 2018). As part of a solution, mostly technical approaches for particular elements of ICT design have been examined (Ballagas et al., 2007; Chiu \& Leung, 2005; Manes, 2001; Paganelli, Bianchi, \& Giuli, 2007; Petersen \& KofodPetersen, 2006) or the ICT shortcomings are partially addressed with the improvement of system's quality and its technical reliability, interacting capabilities, or the service itself (Stankov, Filimonau, \& Slivar, 2018). The development of ICT itself and the evolution of consumer preferences have diminished previously existing issues. For example, there are more proposals that explore the advantages brought by the context-aware systems, social media \& personalisation, and the use of mobile devices for tourism marketing (Buhalis \& Foerste, 2015). Various examples of technology enhanced tourist services within the context of smart tourism demonstrate successful co-creation of richer, more personal, meaningful and memorable experiences, that reverse the possible issues of the ICT proliferation in new value propositions (Gretzel, 2014; Law, Chan, \& Wang, 2018; Yunpeng Li, Hu, Huang, \& Duan, 2017; Neuhofer, 2016; Sigala, 2018). Again, some issues can also be tackled by applying approaches that originate outside the tourism field, such as ambient technology that can be developed for seamless integration of artificial intelligence in all human-populated environments (Cook, Augusto, \& Jakkula, 2009). For some consumers, the solution rests in the complete disconnection from technology (Dickinson et al., 2016; Paris et al., 2015).

Interestingly, the potential of the generic ICT design to address the overall issues caused by the ICT prevalence in the e-tourism context remain unexplored. Concurrently, recent evidence suggests that consumers can benefit from better ICT design (Lim et al., 2018; Stankov, Filimonau, et al., 2018) as it could prevent the unwanted consumption of their attention (Ooi, 
2005) imposed by ICT frictions. Due to the diminished complexity and improved familiarity with technology, the reduced user's focus on technology may be required to ensure that main attention is paid to the actual tourist service (Stankov, Filimonau, et al., 2018). However, the technological intensity of tourism cannot be denied which implies that tourism providers should foresee the growing demand for technology and supply the viable ICT solutions to catch this demand.

Paradoxically, a solution to the technology shortcomings within the e-tourism realm may rest within the technology itself (Case, 2015a; Weiser \& Brown, 1995). More specifically, it may sit within the idea of calm technology (CT) that has become a popular discourse object in ubiquitous computing (Brown, 2016; Case, 2015a; Elwood, 2010; Hohl, 2009; Rogers, 2006; Weiser \& Brown, 1995) but, as such, been overlooked in e-tourism research (Stankov, Filimonau, et al., 2018). CT refers to the context in which technology operates in the background, not calling for full user’s attention at all times (Weiser \& Brown, 1995), having no purpose on its own, but serving in delivering a desired experience instead (Case, 2015a). According to Case (2015a), such technological intervention can also be called 'calm interaction' or 'calm design' (CD). While CD is not a new topic within ICT studies, this paper revives this concept and argues that $\mathrm{CD}$ should be placed at the heart of e-tourism research and practice as the tourism industry is equally affected by the positive and negative implications of ever-accelerating uptake of ICT.

The main goal of the paper is thus to revive the concept of calm technology which originated before the ubiquitous computing era and is now becoming more relevant for tourism, a highly technology dependent industry that increasingly encounters severe frictions in delivering the ICT services. Based on the original ideas from the CT/CD literature, we build the framework to employ calm design in the e-tourism context in order to broaden existing knowledge on calm technology. The findings are then discussed to extend theory on CD towards the domain 
of tourist consumption and to reveal theoretical and practical opportunities for the (re-)design of the tourism product offer.

\section{The evolution of the calm technology (CT) concept}

In linguistic terms, 'calm' represents a state or a condition that is free from agitation, excitement or disturbance (Riekki, Isomursu, \& Isomursu, 2004). In the context of technology, "calm" is predominantly related to the state of a user, and not to a specific application or a piece of hardware that, in most cases, should not shift to its opposite - a “disturbed" state when performing specific tasks or activities with ICT. This allows users to focus on their intended action rather than on the tool they are using (Brown et al., 2017). Therefore, 'calm' technology is an approach to designing tools which is based on user attention and focus (Stankov, Filimonau, et al., 2018)and which is expected to cater for user's demands in a calm manner (Stanford University’s Calming Technology Lab., 2011). Thus, CT describes "any tool that can be used with uninterrupted focus on a central task while the new outside information is easily perceived and processed peripherally” (Brown, Fercher, \& Leitner, 2017, 18).

Weiser and Brown (1995) laid the foundation of CT and raised first concerns regarding potential computer-imposed information overload and subsequent consumer stress (Byrne, O’Grady, \& O’Hare, 2009; Greenfield, 2006). They focused on how technologies should engage both with user's central and peripheral attention. For example, in terms of driving, the driver's central attention is on the road while the driver's peripheral attention is attuned with engine noise (Weiser \& Brown, 1995). Peripheral attention can become central in case of a sudden change in engine noise and should draw driver's attention and prompt them to stop 
and check the engine (Weiser \& Brown, 1995). This easy transition between the two types of user's attention encalms the user. Furthermore, calm technology can bring more detail into the edge of an interface (the periphery) which should increase the user's ability to act when needed without an increased information overload (Weiser \& Brown, 1995). As most of information gained from technology does not require user's full attention, in the simplistic driving example described above the engine light informing the driver about an engine problem will turn on only when relevant (Case, 2015a). In terms of ICT, most notable examples of existing CT are related to calm communication provided as an output of a system, such as the relevant notifications and the different tones recorded for the different statuses of the system or the haptic alerts found in smartwatches and smart bracelets (Stankov, Filimonau, et al., 2018) . For example, some weather mobile applications rely on user's location, context of the use and the upcoming weather conditins to alert the user, but only when needed (Case, 2015b; Grossman, 2015).

CT is relevant to both digital and physical product design. For example, from the perspective of CT, removing focus from technology can be seen in those cases when the small enough ICT devices become embedded into physical features of products or when the ICT devices are not seen as computers anymore but as the augmented artefacts and the (more) natural services (for example, interactive screens, augmented or reality-based games) (Streitz, 2001; Ţugui \& Genete, 2009).

By focusing on how people process information, Weiser and Brown set the basis of CT long time before the ubiquitous computing era. This notwithstanding, the lack of detailed design principles and their accurate quantification have slowed down broad acceptance of the term (Brown et al., 2014). For example, while examples of calm output (information) from a network have been given, no examples of calm input (how to interact) within a network have been provided (Brown, Fercher, \& Leitner, 2017). Therefore, Case (2015a) expands CT, 
suggesting the term calm design (CD), and defines the basic principles that flow from humancentered design, social design, and anthropology, but with the same agenda. Case (2015a) refers to $\mathrm{CD}$ as being very simplistic in a way that it is elegant, humane and unobtrusive (Figure 1). Yet, according to Case (2015a), the principles of CD are not hard-and-fast rules as some are more applicable to specific products, services or users while others are not applicable to them at all; a fire alarm system, for example, should command full people's attention.

\section{[Figure 1 near here]}

As shown in this section, the general effectiveness of ICT is well covered by the existing literature on CT/CD. In the next section, we will discuss the theoretical framework which we have called the calm design for e-tourism (CDET).

\section{Expanding the calm design dimensions towards the e-tourism context}

E-tourism, as a context of dynamic interaction of ICTs in tourism (Buhalis, 2003), has facilitated the development of sophisticated solutions for delivering all sorts of tourism services (Femenia-Serra, Neuhofer, \& Ivars-Baidal, 2018; Law et al., 2014; Navío-Marco, Ruiz-Gómez, \& Sevilla-Sevilla, 2018). Still, e-tourism services cannot be seen as just another context of ICT usage. In terms of co-creating tourist experiences, technology can act as an enabler, creator, attractor, enhancer, protector, educator, substitutor, facilitator, reminder or destroyer (Benckendorff et al., 2014). All of that is happening in the changed environment (both physical and psychological) and within a sector that traditionally welcomes ICT. In the tourism market, consumers may travel to the service provider over longer or shorter distances (Sundbo, 2009). Going on holiday assumes changing user's ICT environment which can 
create additional problems. Ideally, the change from everyday ICT solutions to the ones used during travel and at a destination should not be a cause of unnecessary technology-induced tension and, if problematic for some tourists, this transition in technology use should be addressed by intentional ICT design.

The main goal of CT is in enabling people to cope with the increased amounts of information, thus avoiding over the burden of information overload(Brown et al., 2017).In the case of etourism services, successful calm ICT design draws upon knowledge of a number of variables, including tourist psychology, holiday settings and the tourism industry structure (Gretzel, 2011). Thus, apart from the simple spatial relocation of general ICT use in a calm manner, or technology-related calmness, the complexity of e-tourism services also requires addressing consumer's characteristics towards ICT and the business perspective of the different types of e-tourism services offered in the market that affect calm ICT usage.

Figure 2 depicts the framework of calm design for e-tourism (CDET) starting with the dimension of technology-related calmness based on existing principles (HOW?), that are elaborated upon in previous section (CT/CD). The tourism context is added to calm design in CDET with a new dimension of consumer characteristics (WHO?), such as the different tourist preferences towards ICT or the different travel needs, and the dimension of the types of e-tourism services offered, ranging from a single service provided by tourism supply chain to complex mass or niche tourism offerings at certain types of tourist destinations (WHAT AND WHERE?).

\section{[Figure 2 near here]}

First, we will further elaborate upon a new dimension of consumers' characters (WHO?). This dimension is mostly determined by the users' diversity, referring to various differences 
among customers in their perception, manipulation, and utilization of technology. Stephanidis (2012) suggests that it would be expected that all parties are not equally enthusiastic about the disclosure of ICT within the traditional tourism product offerings. Moreover, what is seen as a mainstream practice today was not taken well by certain customer categories at the time. In terms of demand, Dickinson and collegues (2016) posit that there is always an implicit assumption that tourists welcome and embrace technology while, in reality, there may be a conscious desire to technologically disconnect instead. While some consumers value the pressure or satisfaction from exploring and using new technologies for tourism purposes, they are also concerned about the practicality of these technologies' prolonged use (Yongda Li, 2017). According to innovation theory the group of technology innovators and early adopters would be more willing to engage with the new and unfamiliar technologies (Kah, Vogt, \& MacKay, 2008), comparing to the group of traditionalists when the ICT adoption in concerned. In order to understand the complexity of the dimension of different types of etourism services (WHAT AND WHERE?), an additional analysis will be implemented in the following section.

\section{Analysis of calm design in the different types of e-tourism services}

To retain the theoretical flexibility of the CDET framework and to focus efforts on theoretically useful cases (Eisenhardt, 1989; Neuhofer, Buhalis, \& Ladkin, 2015), the main selection criteria for industry-specific examples are: (1) the use of one of the most common ICTs (Stankov, Pavluković, Alcántara-Pilar, Cimbaljević, \& Armenski, 2018) and; (2) the employment of at least one of the CDET dimensions, for example, ICT is an integral part of e-tourism services, not a distraction (WHAT AND WHERE?) or ICT works in the 
background or it is "hidden”, but still informs users (HOW?); ICT uses simplified or humanoriented user interface (UI) (HOW?); ICT respects the timing and the relevancy of interaction (WHAT AND WHERE?). The review of the academic and 'grey' literature is used to collect the data.

Table 1 elaborates upon selected examples from the broad context of e-tourist services. This encompasses different technology applications and interactions, ranging from online travel promotion and distribution, social media communication, tourist experience enrichment to travel operations and identification systems. It is important to note that presented examples cannot be in any way considered conclusive, but are offered with an intention to spark an academic discussion.

\section{[Table 1 near here]}

As shown in Table 1, the theoretical underpinning of CDET suggests that it can be successfully embraced by the tourism industry as a means to enhance pre-existing and forthcoming technology infrastructure used by tourists. Some calm ICT design principles are already present in the context of mainstream tourist consumption, such as smartphones, wearables and audio and video units. For example, smartphones have become omnipresent and represent a main device for delivering and exchanging all sorts of information (Kim \& Law, 2015), providing personalised information, two-way information sharing, context awareness based on sensors, communication with other machines (IoT), among others (Dickinson et al, 2014). Similarly, wearable technologies have the capabilities to createlocation-based services incorporating travel preferences and body parameters of the users (Choe \& Fesenmaier, 2017; Dibble, 2015). Basically, some existing types ofwearables 
can be noted as good examples of the CT realisation in tourism as they are virtually invisible; small-sized; unobtrusive; easy to use; highly personalised; with sensor-based operations and real time connection to servers. (Stankov, Filimonau, et al., 2018).

At the same time, both smartphones and wearables could be distracting to users. According to Stankov and collegues(2018) such issues poor Internet connectivity frequent need for charging, slow device performance or high roaming charges can be off-putting. In essence, from the CD perspective, communication between humans and -machines is still one of the most important issues to be solved (Case, 2015a),. Generally, the interaction between the device and the user can actually be distracting if the UI attracts most visual or auditory focus due its (design) inconsistency (Case, 2015a; Stankov, Filimonau, et al., 2018)

More sophisticated and less frequently employed hardware and software systems in tourism, such as the various biometric technologies and intelligent software agents and embedded sensors, also hold the strong 'encalming' potential. For example, biometrics , although not being a novelty, have only recently been recognised as a tool for improving the transaction services in travel and tourism industry (Kang, Brewer, \& Bai, 2007). Further, intelligent software agents and the different types of embedded sensors provide calm ICT design with a context of their use, taking into consideration(Hermans, 1998) user's dynamical behaviour (Wang et al., 2013). For example, the geo-enabled mobile applications represent an effortless way of positioning the user on the map(Chung \& Lee, 2016), while the robust technological service enablers are located in the back-end.

\section{Discussion}

\section{Theoretical implications of CDET for the e-tourism discourse}

Adopting pragmatism as a research philosophy and employing an inductive approach, we 
advocate broader application of CDET within the e-tourism discourse. As pragmatism philosophy recognises the different ways of interpreting the actual state of things (Saunders, Lewis, \& Thornhill, 2012), we will discuss the ways of how CDET can be integrated in the current array of ICT solutions adopted by tourism enterprises.

As shown in Figure 2, the travel supply chain has traditionally been technology-intense and technology-demanding (Enrique Bigné, Aldás, \& Andreu, 2008). Its core is made up by the key tourism supply chain actors, such as airlines, hotel and restaurant chains, tourist service providers (for instance, travel management companies-CM, online booking tools-OBT and mobile services), global distribution systems, mid-offices and others. Towards the edge of the core, the level of technology dependence reduces, but does not entirely disappear, and includes small tourist accommodation and catering enterprises, local travel agencies, and other small-to-medium sized companies providing tourist products. This ICT epicentre influences, directly or indirectly, all other players within the tourism market with regard to the products they create, destinations they operate in, and tourists they serve.

On the other side are the tourists who consume products and services in various destinations and, as stated before, who normally have different expectations of the ICT forms and the magnitude of its deployment in tourism (Benckendorff et al., 2014; Jeon, Ali, \& Lee, 2018). The disbalance in the amount of technologies used by the supply and demand side could be mitigated by creating a 'barrier' in the form of CDET, that is, the level of interventions to make the ICT usage 'calmer'.

\section{Theoretical implications of CDET for the 'smart tourism' discourse}

'Smart tourism', as a popular academic topic, also catches much attention in tourism practice and society. As a research discourse, it started with the phase of exploring its content (Buhalis 
\& Amaranggana, 2015; Gretzel, Sigala, et al., 2015; Huang, Yuan, \& Shi, 2012) and underpinning technologies (Atembe, 2015; Chung, Tyan, \& Han, 2017) and now entered the phase of developing and evaluating its applications (Buhalis \& Leung, 2018; Buhalis \& Foerste, 2015; Vecchio, Mele, Ndou, \& Secundo, 2017; X. Wang, Li, Zhen, \& Zhang, 2016). Consequently, the next phase should allow for further diffusion and globalization of smart tourism, enabling the different alternations, enhancements and reinvention of the original starting points (Ryan, 2017; Sigala, 2018). The smart tourism agenda highlights new, more sustainable ways of business management, tourist experience enhancement and destination management that have emerged in the era of ubiquitous computing (Bantau \& Rayburn, 2016; Cannon Hunter, Chung, Gretzel, \& Koo, 2015). This is where CDET can find a fertile ground for its implementation. For example, the trend of further development of smart tourism infrastructure favours the use of miniaturized and simplified assets (for example, sensors and wearables), with no diminished performance, capable to ensure access to various information and to support undisturbing communication (Țugui \& Genete, 2009). On the other hand, CDET could support more humanized smart environments, such as smart homes or smart hotel rooms (Brown et al., 2017). This adoption of CDET could represent a way to moderate future smart tourism efforts in its quest for achieving operational efficiency, economic sustainability and consumer experience enrichment.

\section{Practicalities of the CDET adoption in e-tourism}

For variety of tourism companies, practical knowledge of CDET can be beneficial to better understand the shortcomings of unselective ICT employment for the purpose of creating etourism services. 


\section{Tourism Supply Chain}

The benefits of the CDET embracement by the tourism supply side are manifold and range from the enhanced quality of work and improved delivery of products and services to refined profitability and better customer satisfaction. For example, the Hotel Lugano Dante in Switzerland employs technology to enhance and co-create guest experiences through the adoption of a bespoke digital customer relationship management tool (Neuhofer, Buhalis, \& Ladkin, 2013). Furthermore, CDET can help createnew business models, platforms of corporate communication and collaboration between tourism organisations. An example from Tasmania (Australia) demonstrates an innovative destination management approach to the use of smartphones in order to deduce travel patterns and opinions for specific visitor groups. This has become possible due to a geo-tracking technology; a distinctive feature is however in that this technology is presented to tourists in a 'calm' way through the use of a smartphone with an application running quietly in the background (Sense-T, 2015; Hardy et al., 2017).

\section{Tourism Products}

The development of CDET would require rethinking the digital nature of some tourism products and anticipating shifts to more tangible, l e-tourism solutions in some cases (Hohl, 2009; Stankov, Filimonau, et al., 2018). While the pre- and post-travel phase of tourist experiences can be operated mostly digitally from both the supply and demand side (i.e. epromotion and e-distribution for the supply side and online purchasing and online reviewing for the demand side), the travel phase is largely physically determined, so this is wheremore audio-visual or even tactile communicators can be provided (Stankov, Filimonau, et al., 2018). The calm solutions can range from traditional 'on/off buttons' for in-room devices to voice and light notifications (Wasan, 2014). Furthermore, there are more novel examples of 
the voice assistants' employment in hotels, such as the Amazon Echo hands-free speaker controlled by voice, that enables consumers to completely bypass touch screens or button controls (Ivanov, Webster, \& Berezina, 2017).

\section{Destination Management}

The areas of particular interest from the CDET viewpoint are represented by smart environments and destinations; these seek to deliver practical realisation of the ubiquitous computing vision in everyday scenarios (Byrne et al., 2009). This is achieved via the application of intelligent tourism management systems that facilitate provision of real-time travel updates in tourist transport; delivery of personalised welcoming messages in tourist accommodation; and raised awareness of consumer preferences with a subsequent offer of more personalised customer services (Buhalis \& Amaranggana, 2015; Wang, Li, Zhen, \& Zhang, 2016). However, the ICT-savvy destinations could face challenges in terms of the CDET adoption, as more frequent use of key technologies through social computing and via visual information technologies can equally well enhance tourism services or contribute to information overload (Amadeus, 2007).

It is important to note that, when applied to the branding of tourist destinations or tourism products in general, the term 'calm' can be easily misunderstood in the current tourism marketing context. Some destinations have positioned themselves as providers of stress-free and peaceful surroundings (for instance, the fall foliage destinations in North America or certain rural areas in Ireland). In this case, calming technologies become more relevant, as will be explained in the next section. Going further, in some extreme cases, even the forms of the 'Amish lifestyle' tourist experiences (Trollinger, 2012) are offered. Due to a digital divide, the technology deficient destinations usually sit in underdeveloped and/or remote regions (Drakulić Kovačević et al, 2017). This kind of 'no connectivity zones’ Pearce and 
Gretzel (2012) call the 'dead zones'. The lack of ICT in such destinations can actually impose stress and discomfort on the users accustomed to technology prevalence in their everyday life. The tension and anxiety of being disconnected while travelling is not caused by the lack of technology per se, but largely rests within the consumer's inability to use its functions, such as for the purpose of socialisation, learning, work and play (Paris et al., 2015). Therefore, the inclusion of CDET sits in the opposite corner from the above mentioned experiences. In the realm of CDET, 'calm' destinations are not remote or 'tech free', but the destinations that conceal some unnecessary technological processes or naturally embed ICT solutions into tourism services or provide the mental disappearance of computational artefacts by offering familiar, intuitive and easy-to-employ UI.

\section{Limitations of CDET}

The propositions made in this paper highlight some important limitations of CDET. These fall under the general constraints experienced by tourism providers in their endeavour to adopt new technologies (Wasan, 2014). Still, to enhance competitiveness, small tourism providers have no choice but to engage with ICT innovations (Mihalic \& Buhalis, 2013), although it can impose financial pressure and increase the need for technological expertise in the company. The technological and infrastructural limitations of the contemporary ICT solutions in tourism are still a major issue for calm design (Case, 2015a; Greenfield, 2006; Rogers, 2006). For example, the deployment of biometrics faces the problems of occasional high error rates, delays in processing information, and the need for additional hardware integration (Pato \& Millet, 2010), to mention a few. Sometimes, ubiquitous access to WiFi or mobile network services that is cost-effective and considered as a basic need for modern service delivery can be a major issue for some destinations and types of holidays (Stankov, Filimonau, et al., 2018). Despite numerous advantages of the technological proliferation in tourism, the use of 
ICT that is based on personal data collected during holidays and stored on different servers opens a question of user privacy (Alizadeh, Kanis, \& Veenstra, 2012; Barua, Aimin, \& Hongyi, 2018). This canbe one of the major challenges in general ICT adoption among consumers (Wozniak, Liebrich, Senn, \& Zemp, 2016). Therefore, privacy concerns are one of manifold variables that CDET ought to resolve if applied effectively in tourism.

\section{Further research}

The future development of CDET will depend on its value for end-users and future tourism business interest in the field (Stankov, Filimonau, et al., 2018). Therefore, three main directions for future research can be suggested. First, what could be the best approaches for empirical measurement of 'calmness' in the context of e-tourism services? Developing the appropriate measurement scales for technological 'calmness' (HOW?) in various tourism service contexts (WHAT AND WHERE?) and better consumer segmentation based on their relation to technological 'calmness' (WHO?). Second, an in-depth qualitative analysis of specific applications of CDET is needed for framing viable propositions for ICT redesign and for new product development in the tourism industry. For instance, further research on CDET can be grounded on existing methods of human-computer interactions (Goodwin, 2009) or can start from interaction design (Nielsen, 2013). Third, the tourism offer, when seen as a composition of separate service providers, is highly segmented; it is comprised largely of small-to-medium enterprises with limited technological expertise to efficiently evaluate new ICT solutions (Noh, Song, Park, Yoon, \& Lee, 2016), consumer trends and various scientific and practical approaches that deal with the proliferation issues of ICT and its managerial implications. Thus, the CDET framework could serve as a starting point for encompassing existing knowledge and approaches in ICT design within CT in order to bridge theories into the adoptable managerial framework. This is particularly important for tourism small-to- 
medium enterprises that provide e-tourism services on a day-to-day basis and for those tourism companies that cater to the niche tourist markets whose ICT preferences vary.

\section{Concluding remarks}

This paper does not aim to condemn the excessive use and the growing technology overreliance in the e-tourism context. Instead, it strives to demonstrate a new viewpoint that emphasizes the very-often neglected relations between humans and technologies within the current e-tourism discourse. By its nature, travel as a sort of discontinuity in digitally-led people's lives cannot be totally 'calm'. Indeed, the consumer's initiative to engage with ICT is needed, but the level of this engagement and the desire to sustain it may vary among tourists. Therefore, finding the right place and the right way of the ICT development and integration in tourism services is an ever-lasting question.

\section{References}

Alizadeh, S., Kanis, M., \& Veenstra, M. (2012). Using ambient intelligence to support tourism. In A. J. Spink, F. Grieco, O. E. Krips, L. W. S. Loijens, \& P. H. Noldus, L.P.J.J. Zimmerman (Eds.), Proceedings of Measuring Behavior 2012 (pp. 515-519). Utrecht,. Retrieved from http://kennisbank.hva.nl/en/record/514698

Amadeus. (2007). 2020 Report for the Air Travel Industry. Retrieved from http://www.amadeus.com/documents/future-traveller-tribes-2030/travel-report-future-traveller-tribes2020.pdf

Atembe, R. (2015). The Use of Smart Technology in Tourism: Evidence From Wearable Devices. Journal of Tourism and Hospitality Management, 3(6), 224-234. https://doi.org/10.17265/2328-2169/2015.12.002

Babu, P. (2015). Beacons in Tourism and Travel. Retrieved August 8, 2016, from 
http://blog.beaconstac.com/2015/11/how-beacons-are-transforming-the-travel-industry/

Ballagas, R. A., Kratz, S. G., Borchers, J., Yu, E., Walz, S. P., Fuhr, C. O., ... Tann, M. (2007). REXplorer. In CHI '07 extended abstracts on Human factors in computing systems - CHI '07 (pp. 1929-1934). New York: ACM Press. https://doi.org/10.1145/1240866.1240927

Bantau, G., \& Rayburn, S. W. (2016). Advanced information technology: transforming service innovation and design. The Service Industries Journal, 36(13-14), 699-720. https://doi.org/10.1080/02642069.2016.1272594

Barua, Z., Aimin, W., \& Hongyi, X. (2018). A perceived reliability-based customer satisfaction model in selfservice technology. The Service Industries Journal, 38(7-8), 446-466. https://doi.org/10.1080/02642069.2017.1400533

Benckendorff, P. J., Sheldon, P. J., \& Fesenmaier, D. R. (2014). Tourism Information Technology. Oxfordshire: CABI.

Bilolo, A., Boeck, H., Durif, F., Levesque, N., \& Levesque, N. (2015). The Impact of Proximity Marketing on Consumer Reactions and Firm Performance: A Conceptual and Integrative Model. In Twenty-first Americas Conference on Information Systems - AMCIS 2015 Proceedings (pp. 1-8). Puerto Rico.

Brown, J. N. A. (2016). Anthropology-Based Computing. Cham: Springer International Publishing.

Brown, J. N. A., Bayerl, P. S., Fercher, A., Leitner, G., Catala Mallore, A., \& Hitz, M. (2014). A Measure of Calm. In ACM CHI Conference on Human Factors in Computing Systems. Retrieved from http://peripheralinteraction.id.tue.nl/chi/paper/CHIWorkshop_PI_Brown2.pdf

Brown, J. N. A., Fercher, A. J., \& Leitner, G. (2017). “Just the Place for a Snark!”: An Introduction to Calm Technology. In J. N. . Brown, A. J. Ferchera, \& G. Leitner (Eds.), Building an Intuitive Multimodal Interface for a Smart Home (pp. 17-20). Cham: Springer.

Buhalis, D. (2003). ETourism: information technology for strategic tourism management. London: Financial Times Prentice Hall.

Buhalis, D., \& Amaranggana, A. (2015). Smart Tourism Destinations Enhancing Tourism Experience Through Personalisation of Services. In I. Tussyadiah \& A. Inversini (Eds.), Information and Communication Technologies in Tourism 2015 (pp. 377-389). Cham: Springer International Publishing. https://doi.org/10.1007/978-3-319-14343-9_28 
Buhalis, D., \& Foerste, M. (2015). SoCoMo marketing for travel and tourism: Empowering co-creation of value. Journal of Destination Marketing \& Management, 4(3), 151-161. https://doi.org/10.1016/j.jdmm.2015.04.001

Buhalis, D., \& Leung, R. (2018). Smart hospitality-Interconnectivity and interoperability towards an ecosystem. International Journal of Hospitality Management, 71, 41-50. https://doi.org/10.1016/J.IJHM.2017.11.011

Byrne, C., O’Grady, M., \& O’Hare, G. (2009). Ambient Intelligence in Perspective. In J. Symonds (Ed.), Ubiquitous and Pervasive Computing: Concepts, Methodologies, Tools, and Applications (pp. 129-136). Harshey: IGI Global. https://doi.org/10.4018/978-1-60566-960-1.ch011

Cannon Hunter, W., Chung, N., Gretzel, U., \& Koo, C. (2015). Constructivist Research in Smart Tourism. Asia Pacific Journal of Information Systems, 25(1), 105-120.

Case, A. (2015a). Calm technology: Principles and patterns for non-intrusive design. Sebastopol: CA: O’Reilly Media, Inc,

Case, A. (2015b). The future of the internet is calm. Retrieved August 8, 2016, from http://orangesv.com/blog/the-future-of-the-internet-is-calm/

Chiu, D. K. W., \& Leung, H. (2005). Towards Ubiquitous Tourist Service Coordination and Integration: a MultiAgent and Semantic Web Approach semantic web services. In Proceedings of the 7th international conference on Electronic commerce - ICEC '05 (pp. 574-581). New York, New York, USA: ACM Press. https://doi.org/10.1145/1089551.1089656

Choe, Y., \& Fesenmaier, D. R. (2017). The Quantified Traveler: Implications for Smart Tourism Development. In Z. Xiang \& D. R. Fesenmaier (Eds.), Analytics in Smart Tourism Design (pp. 65-77). Springer International Publishing. https://doi.org/10.1007/978-3-319-44263-1_5

Chung, N., \& Lee, H. (2016). Sharing economy in geotag: what are the travelers' goals sharing their locations by using geotags in social network sites during the tour? International Journal of Tourism Cities, 2(2), 125136. https://doi.org/10.1108/IJTC-08-2015-0022

Chung, N., Tyan, I., \& Han, H. (2017). Enhancing the smart tourism experience through geotag. Information Systems Frontiers, 19(4), 731-742. https://doi.org/10.1007/s10796-016-9710-6

Clark, A. (2014). How emoji became the first truly global language | Technology | The Guardian. Retrieved from 
https://www.theguardian.com/technology/2014/aug/31/emoji-became-first-global-language

Cook, D. J., Augusto, J. C., \& Jakkula, V. R. (2009). Ambient intelligence: Technologies, applications, and opportunities. Pervasive and Mobile Computing, 5(4), 277-298. https://doi.org/10.1016/j.pmcj.2009.04.001

Cousins, C. (2015). Google Material Design: Everything You Need to Know | Design Shack. Retrieved August 8, 2016, from https://designshack.net/articles/ux-design/google-material-design-everything-you-need-toknow/

Cunningham, P. (2016). No more lost in translation - smart earpiece to translate foreign languages instantly for travellers. Retrieved July 19, 2016, from Lonely Planet Travel News

Dajani, H. (2017). Dubai airport’s new virtual aquarium tunnel scans your face as you walk through it - The National.

Dibble, T. (2015). Technology is changging travel. Retrieved July 18, 2015, from https://www.screenpilot.com/2015/03/wearables-wanderlust-how-technology-is-changing-travel/

Dickinson, J. E., Ghali, K., Cherrett, T., Speed, C., Davies, N., \& Norgate, S. (2014). Tourism and the smartphone app: capabilities, emerging practice and scope in the travel domain. Current Issues in Tourism, 17(1), 84-101. https://doi.org/http://dx.doi.org/10.1080/13683500.2012.718323

Dickinson, J. E., Hibbert, J. F., \& Filimonau, V. (2016). Mobile technology and the tourist experience: (Dis)connection at the campsite. Tourism Management, 57, 193-201. https://doi.org/10.1016/j.tourman.2016.06.005

Eisenhardt, K. M. (1989). Building Theories from Case Study Research. The Academy of Management Review, 14(4), 532. https://doi.org/10.2307/258557

Elwood, S. A. (2010). Embedding Ubiquitous Technologies. In J. Symonds (Ed.), Ubiquitous and Pervasive Computing: Concepts, Methodologies, Tools, and Applications (pp. 511-519). Hershley: IGI Global. https://doi.org/10.4018/978-1-60566-960-1.ch033

Enrique Bigné, J., Aldás, J., \& Andreu, L. (2008). B2B services: IT adoption in travel agency supply chains. Journal of Services Marketing, 22(6), 454-464. https://doi.org/10.1108/08876040810901873

ETC, \& UNWTO. (2014). Handbook on E-marketing for Tourism Destinations - Fully revised and extended version 3.0. Madrid: ETC; UNWTO. 
Eye for Travel. (2016). Talking technology: is this what hotel guests really want? Retrieved August 8, 2016, from http://www.eyefortravel.com/mobile-and-technology/talking-technology-what-hotel-guests-reallywant

Femenia-Serra, F., Neuhofer, B., \& Ivars-Baidal, J. A. (2018). Towards a conceptualisation of smart tourists and their role within the smart destination scenario. The Service Industries Journal, 1-25. https://doi.org/10.1080/02642069.2018.1508458

First Round Review. (2017). Amazon’s Friction-Killing Tactics To Make Products More Seamless | First Round Review. Retrieved April 15, 2018, from http:/firstround.com/review/amazons-friction-killing-tactics-tomake-products-more-seamless/

Frıás, D. M. A., Rodrıuez, M. A., \& Castanda, J. A. (2008). Internet vs . travel agencies on pre - visit destination image formation: An information processing view. Tourism Management, 29, 163-179.

Goodwin, K. (2009). Designing for the digital age: How to create human-centered products and services. Indianapolis: Wiley Pub.

Greenfield, A. (2006). Everyware The dawning age of ubiquitous computing. Berkley: New Riders.

Gretzel, U. (2011). Intelligent systems in tourism. Annals of Tourism Research, 38(3), 757-779. https://doi.org/10.1016/j.annals.2011.04.014

Gretzel, U. (2014). Travel Unplugged: The case of Lord Howe Island, Australia. In K. Mackay (Ed.), TProceedings of the TTRA Canada’ Annuual Conference. Yellowknife. Retrieved from https://www.researchgate.net/profile/Ulrike_Gretzel2/publication/279748727_Travel_Unplugged_The_cas e_of_Lord_Howe_Island_Australia/links/5598f5b508ae793d137e24fe

Gretzel, U., Sigala, M., Xiang, Z., \& Koo, C. (2015). Smart tourism: foundations and developments. Electronic Markets, 25(3), 179-188. https://doi.org/10.1007/s12525-015-0196-8

Gronflaten, O. (2009). Predicting Travelers’ Choice of Information Sources and Information Channels. Journal of Travel Research, 48(2), 230-244. https://doi.org/10.1177/0047287509332333

Grossman, A. (2015). Forecast Blog: Dark Sky 5. Retrieved September 3, 2015, from http://blog.forecast.io/dark-sky-5/

Guttentag, D. A. (2010). Virtual reality: Applications and implications for tourism. Tourism Management, 31(5), 637-651. https://doi.org/10.1016/j.tourman.2009.07.003 
Hecht, B., Schöning, J., Erickson, T., \& Priedhorsky, R. (2011). Geographic Human-Computer Interaction. In CHI '11 Extended Abstracts on Human Factors in Computing Systems (pp. 447-450). Vancouver: AMC Press. Retrieved from http://www-users.cs.umn.edu/ bhecht/publications/bhecht_chi2011_geohci.pdf

Hermans, B. (1998). Desperately Seeking: Helping Hands and Human Touch. First Monday Peer-Reviewed Journal on the Internet, 3(11). https://doi.org/10.5210/fm.v3i11.626

Hilton. (2017). Hilton Announces ‘Connected Room,’ The First Mobile-Centric Hotel Room, To Begin Rollout in 2018| Hilton Global Media Center. Retrieved January 3, 2018, from http://newsroom.hilton.com/index.cfm/news/hilton-announces-connected-room-the-first-mobilecentrichotel-room-to-begin-rollout-in-2018

Hohl, M. (2009). Calm Technologies 2.0: Visualising Social Data as an Experience in Physical Space. Parsons Journal for Information Mapping, 1(3), 1-7.

Huang, X., Yuan, J., \& Shi, M. (2012). Condition and Key Issues Analysis on the Smarter Tourism Construction in China. In F. L. Wang, J. Lei, R. W. H. Lau, \& J. Zhang (Eds.), Multimedia and Signal Processing (pp. 444-450). Berlin: Springer.

Ivanov, S. H., Webster, C., \& Berezina, K. (2017). Adoption of Robots and Service Automation by Tourism and Hospitality Companies, 27/28, 1501-1517.

Jeon, H.-M., Ali, F., \& Lee, S.-W. (2018). Determinants of consumers' intentions to use smartphones apps for flight ticket bookings. The Service Industries Journal, 1-18. https://doi.org/10.1080/02642069.2018.1437908

Jung, S., (Sunny) Kim, J., \& Farrish, J. (2014). In-room technology trends and their implications for enhancing guest experiences and revenue. Journal of Hospitality and Tourism Technology, 5(3), 210-228. https://doi.org/10.1108/JHTT-11-2013-0035

Kah, J. A., Vogt, C., \& MacKay, K. (2008). Online Travel Information Search and Purchasing by Internet Use Experiences. Information Technology \& Tourism, 10(3), 227-243.

Kang, B., Brewer, K. P., \& Bai, B. (2007). Biometrics for Hospitality and Tourism: A New Wave of Information Technology. Hospitality Review, 25(1), 1-9.

Kim, H. H., \& Law, R. (2015). Smartphones in Tourism and Hospitality Marketing: A Literature Review. Journal of Travel \& Tourism Marketing, 32(6), 692-711. https://doi.org/10.1080/10548408.2014.943458 
Law, R., Buhalis, D., \& Cobanoglu, C. (2014). Progress on information and communication technologies in hospitality and tourism. International Journal of Contemporary Hospitality Management, 26(5), 727-750. https://doi.org/10.1108/IJCHM-08-2013-0367

Law, R., Chan, I. C. C., \& Wang, L. (2018). A comprehensive review of mobile technology use in hospitality and tourism. Journal of Hospitality Marketing \& Management, 1-23. https://doi.org/10.1080/19368623.2018.1423251

Lee, Y.-K., Chang, C.-T., Lin, Y., \& Cheng, Z.-H. (2014). The dark side of smartphone usage: Psychological traits, compulsive behavior and technostress. Computers in Human Behavior, 31, 373-383. https://doi.org/10.1016/j.chb.2013.10.047

Li, Y. (2017). Individuals’ Motivations to Adopt Smart Technologies for Tourism - Discrepancy Between Initial and Post Adoption. In N. Streitz \& Markopoulos. Panos (Eds.), Distributed, Ambient and Pervasive Interactions (pp. 77-92). Cham: Springer.

Li, Y., Hu, C., Huang, C., \& Duan, L. (2017). The concept of smart tourism in the context of tourism information services. Tourism Management, 58, 293-300. https://doi.org/10.1016/J.TOURMAN.2016.03.014

Lim, W. M., Teh, P.-L., Ahmed, P. K., Cheong, S.-N., Ling, H.-C., \& Yap, W.-J. (2018). Going keyless for a seamless experience: Insights from a unified hotel access control system. International Journal of Hospitality Management, 75, 105-115. https://doi.org/10.1016/J.IJHM.2018.03.014

Magnini, V. (2017). Designing Tourism Services in an Era of Information Overload. In D. R. Fesenmaier \& Z. Xiang (Eds.), Design Science in Tourism (pp. 161-172). Cham: Springer. https://doi.org/10.1007/978-3319-42773-7_11

Manes, G. (2001). The Tetherless Tourist: Ambient Intelligence in Travel \& Tourism. Information Technology \& Tourism, 5(4), 211-220.

Meehan, K., Lunney, T., Curran, K., \& McCaughey, A. (2013). Context-aware intelligent recommendation system for tourism. In 2013 IEEE International Conference on Pervasive Computing and Communications Workshops (PERCOM Workshops) (pp. 328-331). San Diego: IEEE. https://doi.org/10.1109/PerComW.2013.6529508

Mihalic, T., \& Buhalis, D. (2013). ICT as a new competitive advantage factor-case of small transitional Hotel 
Sector. Economic and Business Review, 15(1), 33-56.

Navío-Marco, J., Ruiz-Gómez, L. M., \& Sevilla-Sevilla, C. (2018). Progress in information technology and tourism management: 30 years on and 20 years after the internet - Revisiting Buhalis \&amp; Law’s landmark study about eTourism. Tourism Management, 69, 460-470. https://doi.org/10.1016/J.TOURMAN.2018.06.002

Neuhofer, B. (2016). Value Co-creation and Co-destruction in Connected Tourist Experiences. In A. Inversini \& R. Schegg (Eds.), Information and Communication Technologies in Tourism 2016 (pp. 779-792). Cham: Springer International Publishing. https://doi.org/10.1007/978-3-319-28231-2_56

Neuhofer, B., Buhalis, D., \& Ladkin, A. (2013). High Tech for High Touch Experiences: A Case Study From the Hospitality Industry. In L. Cantoni \& Z. P. Xiang (Eds.), Information and Communication Technologies in Tourism 2013 (pp. 290-301). Berlin, Heidelberg: Springer Berlin Heidelberg. https://doi.org/10.1007/9783-642-36309-2_25

Neuhofer, B., Buhalis, D., \& Ladkin, A. (2014). A Typology of Technology-Enhanced Tourism Experiences. International Journal of Tourism Research, 16(4), 340-350. https://doi.org/10.1002/jtr.1958

Neuhofer, B., Buhalis, D., \& Ladkin, A. (2015a). Smart technologies for personalized experiences: a case study in the hospitality domain. Electronic Markets, 25(3), 243-254. https://doi.org/10.1007/s12525-015-0182-1

Neuhofer, B., Buhalis, D., \& Ladkin, A. (2015b). Technology as a Catalyst of Change: Enablers and Barriers of the Tourist Experience and Their Consequences. In I. Tussyadiah \& A. Inversini (Eds.), Information and Communication Technologies in Tourism 2015 (pp. 789-802). Cham: Springer International Publishing. https://doi.org/10.1007/978-3-319-14343-9_57

Nielsen, L. (2013). Personas - User focused design. London: Springer Verlang.

Noh, H., Song, Y., Park, A.-S., Yoon, B., \& Lee, S. (2016). Development of new technology-based services. The Service Industries Journal, 36(5-6), 200-222. https://doi.org/10.1080/02642069.2016.1165673

Ooi, C.-S. (2005). A Theory of Tourism Experiences: The Management of Attention. In T. O’Dell \& P. Billing (Eds.), Experiencescapes: Tourism, Culture and Economy (pp. 51-68). Herndon: Copenhagen Business School Press.

Paganelli, F., Bianchi, G., \& Giuli, D. (2007). A Context Model for Context-Aware System Design Towards the Ambient Intelligence Vision: Experiences in the eTourism Domain. In Universal Access in Ambient 
Intelligence Environments (pp. 173-191). Berlin, Heidelberg: Springer Berlin Heidelberg. https://doi.org/10.1007/978-3-540-71025-7_12

Paris, C. M., Berger, E. A., Rubin, S., \& Casson, M. (2015). Disconnected and Unplugged: Experiences of Technology Induced Anxieties and Tensions While Traveling. In I. Tussyadiah \& A. Inversini (Eds.), Information and Communication Technologies in Tourism 2015 (pp. 803-816). Cham: Springer International Publishing. https://doi.org/10.1007/978-3-319-14343-9_58

Pato, J. N., \& Millet, L. i. (2010). Biometric Recognition: Challenges and Opportunities. Washington, D.C.: National Academies Press.

Pearce, P., \& Gretzel, U. (2012). Tourism in technology dead zones: documenting experiential dimensions. International Journal of Tourism Sciences, 12(2), 1-20.

Peng, C., Chen, B.-Y., \& Tsai, C.-H. (2010). Integrated Google Maps and smooth street view videos for route planning. In 2010 International Computer Symposium (ICS2010) (pp. 319-324). IEEE. https://doi.org/10.1109/COMPSYM.2010.5685494

Pesonen, J., \& Horster, E. (2012). Near field communication technology in tourism. Tourism Management Perspectives, 4, 11-18. https://doi.org/10.1016/j.tmp.2012.04.001

Petersen, S. A., \& Kofod-Petersen, A. (2006). The Non-Accidental Tourist:Using Ambient Intelligence For Enhancing Tourist Experiences. In L. M. Camarinha-Matos, H. Afsarmanesh, \& M. Ollus (Eds.), NetworkCentric Collaboration and Supporting Frameworks (pp. 619-626). Boston: Springer. https://doi.org/10.1007/978-0-387-38269-2_65

Plé, L., \& Chumpitaz Cáceres, R. (2010). Not always co -creation: introduc value in service Idømialabf Segvices Marketing, 24(6), 430-437. https://doi.org/10.1108/08876041011072546

Riekki, J., Isomursu, P., \& Isomursu, M. (2004). Evaluating the Calmness of Ubiquitous Applications. In F. Bomarius \& H. Iida (Eds.), Product Focused Software Process Improvement (pp. 105-119). Berlin: Springer Berlin Heidelberg. https://doi.org/10.1007/978-3-540-24659-6_8

Rogers, Y. (2006). Moving on from Weiser’s Vision of Calm Computing: Engaging UbiComp Experiences. In P. Dourish \& A. Friday (Eds.), UbiComp 2006: Ubiquitous Computing (Vol. 4206, pp. 404-421). Berlin: Springer-Verlag. 
Ryan, C. (2017). Future trends in tourism research - Looking back to look forward: The future of 'Tourism Management Perspectives.’ Tourism Management Perspectives. https://doi.org/10.1016/J.TMP.2017.12.005

Saunders, M., Lewis, P., \& Thornhill, A. (2012). Research methods for business students. Harlow: Pearson.

Sense-T. (2015). World-leading tourism tracking research hits the road - Sense-T - from sensing to intelligence. Retrieved August 1, 2016, from http://www.sense-t.org.au/latest-news/news-items/world-leading-tourismtracking-research-hits-the-road

Shroeder, S. (2015). Google Flights will now show you which flights have Wi-Fi. Retrieved July 18, 2015, from http://mashable.com/2015/03/13/google-flights-wifi-routehappy/\#VLIu7TwOCZqd

Sigala, M. (2017). Value co-destruction in service ecosystems: findings from TripAdvisor. In S. Marianna \& G. Ulrike (Eds.), Advances in social media for travel, tourism and hospitality (pp. 26-40). London: Routledge.

Sigala, M. (2018). New technologies in tourism: From multi-disciplinary to anti-disciplinary advances and trajectories. Tourism Management Perspectives. https://doi.org/10.1016/j.tmp.2017.12.003

Stanford University’s Calming Technology Lab. (2011). Calming Technology: So what are “calm” technologies, then? Retrieved July 7, 2016, from http://calmingtechnology.org/post/48795961169/so-what-are-calmtechnologies-then

Stankov, U., Filimonau, V., \& Slivar, I. (2018). Calm ICT design in hotels: A critical review of applications and implications. International Journal of Hospitality Management. Retrieved from 10.1016/j.ijhm.2018.10.012

Stankov, U., Pavluković, V., Alcántara-Pilar, J. M., Cimbaljević, M., \& Armenski, T. (2018). Should Festival Be Smarter? ICT on Mass Events - The Case of the Exit Festival (Novi Sad, Serbia). In J. M. . Rodrigues, C. M. . Ramos, P. J. . Cardoso, \& C. Henriques (Eds.), Handbook of Research on Technological Developments for Cultural Heritage and eTourism Applications (pp. 245-263). Hershey: IGI Global.

Stephanidis, C. (2012). The Encyclopedia of Human-Computer Interaction. In The Encyclopedia of HumanComputer Interaction, 2nd Ed. (2nd ed.). Interaction Design Foundation. Retrieved from http://damss.dropmark.com/253007/10477581

Sundbo, J. (2009). Innovation in the experience economy: a taxonomy of innovation organisations. The Service 
Industries Journal, 29(4), 431-455. https://doi.org/10.1080/02642060802283139

Szutowski, D. (2018). Innovation source, advancement stage and company stock returns. The Service Industries Journal, 1-18. https://doi.org/10.1080/02642069.2018.1450869

Tarlow, P. (2011). The World of Technology Affects Tourism Industry Immensely. Retrieved August 11, 2016, from http://www.tourism-review.com/the-world-of-technology-affects-tourism-industry-immenselynews 2757

The Japan News. (2016). Fingerprints to be tested as ‘currency’ - The Japan News. Retrieved from http://thejapan-news.com/news/article/0002859676

Ting, D. (2016). The Current State of Keyless Entry at Big Hotel Brands. Retrieved August 8, 2016, from https://skift.com/2016/06/29/the-current-state-of-keyless-entry-at-big-hotel-brands/

Trollinger, S. L. (2012). Selling the Amish - The Tourism of Nostalgia. Baltimore: Johns Hopkins University Press.

Ţugui, A., \& Genete, L.-D. (2009). Information Technologies in the Calm Technologies Era. Communications of the IBIMA, 8, 120-127.

Vecchio, P. Del, Mele, G., Ndou, V., \& Secundo, G. (2017). Creating value from Social Big Data: Implications for Smart Tourism Destinations. Information Processing \& Management, 54(5), 847-860. https://doi.org/10.1016/J.IPM.2017.10.006

Vong, K. (2012). How Technology in Tourism is Taking Travel to the Next Level. Retrieved August 7, 2016, from http://www.trendreports.com/article/technology-in-tourism

Wang, X., Li, X. (Robert), Zhen, F., \& Zhang, J. (2016). How smart is your tourist attraction?: Measuring tourist preferences of smart tourism attractions via a FCEM-AHP and IPA approach. Tourism Management, 54, 309-320. https://doi.org/10.1016/j.tourman.2015.12.003

Wang, Z., Zhu, W., Cui, P., Sun, L., \& Yang, S. (2013). Social Media Recommendation. In N. Ramzan, R. van Zwol, J.-S. Lee, K. Clüver, \& X.-S. Hua (Eds.), Social Media Retrieval (pp. 23-42). London: Springer Verlang. https://doi.org/10.1007/978-1-4471-4555-4_2

Wasan, P. (2014). Sustainable Technology in Hospitality Industry. In V. Jauhari (Ed.), Managing Sustainability in the Hospitality and Tourism Industry Paradigms and Directions for the Future (pp. 101-135). Boca Raton, FL; Oakville, ON: CRC Press; Apple Academic Press. https://doi.org/10.1046/9999-9999.99999 
Weiser, M., \& Brown, J. S. (1995). Designing Calm Technology. Retrieved May 5, 2016, from http://www.ubiq.com/weiser/calmtech/calmtech.htm

Williams, O. (2015). Hyde Park visitors covertly tracked via mobile phone data. Retrieved July 18, 2015, from https://www.theguardian.com/world/2015/dec/25/hyde-park-visitors-tracked-mobile-phone-data-ee

Wozniak, T., Liebrich, A., Senn, Y., \& Zemp, M. (2016). Alpine Tourists’ Willingness to Engage in Virtual CoCreation of Experiences. In A. Inversini \& R. Schegg (Eds.), Information and Communication Technologies in Tourism 2016 (pp. 281-294). Cham: Springer International Publishing. https://doi.org/10.1007/978-3-319-28231-2_21

Yoo, C. W., Goo, J., Huang, C. D., Nam, K., \& Woo, M. (2017). Improving travel decision support satisfaction with smart tourism technologies: A framework of tourist elaboration likelihood and self-efficacy. Technological Forecasting and Social Change, 123, 330-341. https://doi.org/10.1016/J.TECHFORE.2016.10.071 
Table 1. Examples and explanations of the CDET dimensions in current and future etourism contexts (Source: compiled by authors)

\begin{tabular}{|c|c|c|}
\hline $\begin{array}{l}\text { Supporting } \\
\text { technology } \\
\text { infrastructure }\end{array}$ & Examples & Major CDET dimensions \\
\hline \multirow[t]{5}{*}{ Smartphones } & $\begin{array}{l}\text { Roadside America mobile application (Vong, } \\
\text { 2012) }\end{array}$ & $\begin{array}{l}\text { How? Applications working in the background } \\
\text { What and where? Relevant notifications and } \\
\text { contextual push mobile notifications }\end{array}$ \\
\hline & $\begin{array}{l}\text { Anonymised mobile phone data tracking trail } \\
\text { in London's Hyde Park undertaken by Royal } \\
\text { Parks (Williams, 2015) }\end{array}$ & $\begin{array}{l}\text { How? Visitors tracking without their active } \\
\text { participation; } \\
\text { Who? Everybody }\end{array}$ \\
\hline & Smart posters (Pesonen\& Horster, 2012) & $\begin{array}{l}\text { How? "Hidden” ICT } \\
\text { What and where? Pull notifications at consumers' } \\
\text { convenience. }\end{array}$ \\
\hline & $\begin{array}{l}\text { iBeacon airport mobile application (Babu, } \\
\text { 2015) }\end{array}$ & $\begin{array}{l}\text { What and where? Opt-in push notifications } \\
\text { Who? Tech-dependant consumers }\end{array}$ \\
\hline & Starwood's keyless mobile entry (Ting, 2016) & $\begin{array}{l}\text { What and where? Self-directed experiences } \\
\text { Who? Tech-dependant consumers }\end{array}$ \\
\hline \multirow[t]{2}{*}{ Wearables } & $\begin{array}{l}\text { Radio-frequency identification (RFID) festival } \\
\text { bracelets(Bilolo, Boeck, Durif, Levesque, \& } \\
\text { Levesque, 2015) }\end{array}$ & $\begin{array}{l}\text { How? Contactless identification, embedded } \\
\text { technology Who? Everybody }\end{array}$ \\
\hline & $\begin{array}{l}\text { Near-field communication (NFC) enabled } \\
\text { wearables (Pesonen \& Horster, 2012) }\end{array}$ & $\begin{array}{l}\text { What and where?Relevant location-based travel } \\
\text { operations and proximity services }\end{array}$ \\
\hline \multirow[t]{2}{*}{$\begin{array}{l}\text { Biometric } \\
\text { identification } \\
\text { technology }\end{array}$} & $\begin{array}{l}\text { Fingerprint authentication system for } 2020 \\
\text { Tokyo Olympic and Paralympic Games (The } \\
\text { Japan News, 2016) }\end{array}$ & $\begin{array}{l}\text { How? Paperless transaction } \\
\text { What and where? Frictionless shopping }\end{array}$ \\
\hline & $\begin{array}{l}\text { Prototype of airport's virtual aquarium tunnel } \\
\text { (Dajani, 2017) }\end{array}$ & $\begin{array}{l}\text { How? Identification with hidden and pleasant } \\
\text { technology that scans passengers' face as they walk } \\
\text { through it } \\
\text { Who? Everybody }\end{array}$ \\
\hline \multirow[t]{4}{*}{$\begin{array}{l}\text { Audiovisual } \\
\text { technologies }\end{array}$} & Google Material design (Cousins, 2015) & $\begin{array}{l}\text { How? Unified user experiences for e-info points } \\
\text { Who? Everybody }\end{array}$ \\
\hline & $\begin{array}{l}\text { Google Street View (Peng, Chen, \& Tsai, } \\
\text { 2010) }\end{array}$ & $\begin{array}{l}\text { How? Virtual reality functions on websites that } \\
\text { employ human-centred visual communication }\end{array}$ \\
\hline & $\begin{array}{l}\text { Use of emojis in delivering information (Clark, } \\
\text { 2014); Smart ear-piece for instant translation } \\
\text { (Cunningham, 2016) }\end{array}$ & $\begin{array}{l}\text { How? Removing language barriers } \\
\text { Who? Millennials }\end{array}$ \\
\hline & $\begin{array}{l}\text { Amazon Echo for hotel rooms (Eye for Travel, } \\
\text { 2016) }\end{array}$ & $\begin{array}{l}\text { How? Human-centred audio communication } \\
\text { What and where? Enhanced hotel experience }\end{array}$ \\
\hline \multirow{5}{*}{$\begin{array}{l}\text { Intelligent } \\
\text { software } \\
\text { agents, } \\
\text { embedded } \\
\text { sensors and } \\
\text { geolocation } \\
\text { systems }\end{array}$} & $\begin{array}{l}\text { PixMeAway and Routhappy (Neuhofer, } \\
\text { Buhalis, \& Ladkin, 2014; Shroeder, 2015) }\end{array}$ & $\begin{array}{l}\text { What and where? Proactive websites services for } \\
\text { reducing information and choice overload } \\
\text { Who? Everybody }\end{array}$ \\
\hline & $\begin{array}{l}\text { Facebook users' personal news feed (ETC \& } \\
\text { UNWTO, 2014) }\end{array}$ & $\begin{array}{l}\text { What and where? Contextual social media } \\
\text { notifications and promotions }\end{array}$ \\
\hline & Hilton's Connected Room (Hilton, 2017) & $\begin{array}{l}\text { What and where? Hyper-personalized hotel room } \\
\text { experience that links everyday and on-site ICT. }\end{array}$ \\
\hline & $\begin{array}{l}\text { Google Earth; Bing maps (Hecht, Schöning, } \\
\text { Erickson, \& Priedhorsky, 2011) }\end{array}$ & $\begin{array}{l}\text { How? Online maps or mobile maps for intuitive use } \\
\text { with no beforehand training }\end{array}$ \\
\hline & $\begin{array}{l}\text { Social media geo-tagging (Chung \& Lee, } \\
\text { 2016) }\end{array}$ & What and where? Simple end-user geo-tagging \\
\hline
\end{tabular}




\section{Figure captions}

Figure 1. Qualitative principles of calm design. Source: Adopted from Case (2015a)

Figure 2. The framework of calm design for e-tourism. Source: Authors’ own compilation. 